J. IÑAKI DE LA PEÑA, Ph.D. ${ }^{1}$

(Corresponding Author)

E-mail: jinaki.delapena@ehu.es

MIGUEL A. PEÑA-CEREZO, Ph.D. ${ }^{2}$

E-mail: miguelangel.pena@ehu.es

OLGA FOTINOPOULOU, Ph.D. ${ }^{2}$

E-mail: olga.fotinopulos@ehu.es

${ }^{1}$ Faculty of Economics and Business,

University of the Basque Country (UPV/EHU)

Financial Economics I Department

Avda. Lehendakari Agirre, 83, 48015 Bilbao, Spain

${ }^{2}$ Faculty of Economics and Business,

University of the Basque Country (UPV/EHU)

Financial Economics II Department

C/ Comandante Izarduy, 23, 01006 Vitoria-Gasteiz, Spain
Transport Economics Original Scientific Paper Submitted: 25 Feb. 2019 Accepted: 2 Dec. 2019

\title{
COST OF PRODUCTION LOSS FOR LONG-TERM DISABILITY DUE TO ROAD CRASHES
}

\begin{abstract}
Traffic accidents leave lifelong after-effects and if the victim is disabled, they produce a production loss due to the differential in income that will be lost. This average value is very divergent in European countries, although there is consensus on cost components and valuation methods. However, many countries have legally standardised financial compensation so that it is calculated objectively and equitably for all those affected. This paper sets out the procedure for standardising the lost production cost of incapacitated road accident victims. An actuarial methodology relating to known inputs (age and salary) is used to obtain economic compensation for lost productivity. General principles and hypotheses are provided, and cases that require particular valuation are located. The standard cost thus calculated allows a homogeneous, fair and equitable compensation for all those involved in similar circumstances.
\end{abstract}

\section{KEY WORDS}

road crash; injury; disability; value of life; actuarial valuation,

\section{INTRODUCTION}

Traffic accidents affect the health/lives and finances of victims and of those around them (family, business). They generate medical expenses, disability, production loss and legal and administrative costs $[1,2]$. Furthermore, if the head of a family dies due to a traffic accident, the family's risk of poverty increases [3]. Road crashes also represent an economic burden on the national economy; thus, the working age population contributes to the country Gross
Domestic Product (GDP). Having an accident that results in disability undermines an individual's productive capacity and, therefore, they do not contribute to GDP.

Some international organisations [4-6] have warned of reducing the consequences of car accidents, both for society and for accident victims. It is therefore, common to find national and international studies from different viewpoints from governments, insurance companies, citizens or from victims themselves. Most studies calculate the socio-economic effect of road crashes on a country. This implies that the cost is estimated globally without taking into account the specific group affected by the cost (insurers, government, individuals, etc.), and this information may be relevant for establishing public policies to prevent and reduce accidents or to assess the effectiveness of the measures taken to prevent them.

The SafetyCube project [7] estimates the socio-economic cost of road accidents for Europe to be 205,746 million euro in 2015 (Figure 1), where France, Germany and Italy already account for 50\% of this cost. This figure brings together different components (medical, loss of work, moral damage, material damage, administrative damage, etc.), some of which are easily valued whereas other costs are more subjective and often end up being decided in the courts of law.

A part of these costs is valued in insurance companies' accounts. Thus, in 2016, vehicle accidents generated more than $€ 3,040$ million in compensation 


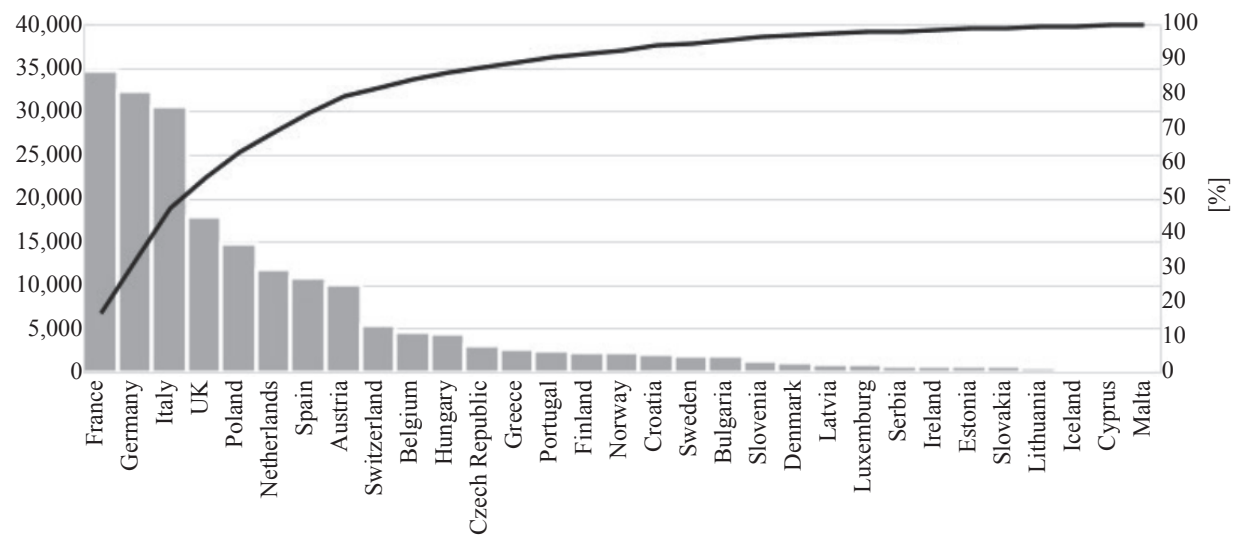

Figure 1 - Cost of road crashes in millions of euro (2015) [7]

to Spanish insurers. This figure represents part of the impact of traffic accidents on the population economy.

In addition to deaths, there are serious injuries that generally require health care since they often leave lifelong sequelae because they cause some degree of disability and generate high economic costs, both medical and social. Future economic losses include the costs that a victim will have to bear (emerging damage) and the income that will be lost as a result of an accident (loss of earnings). On

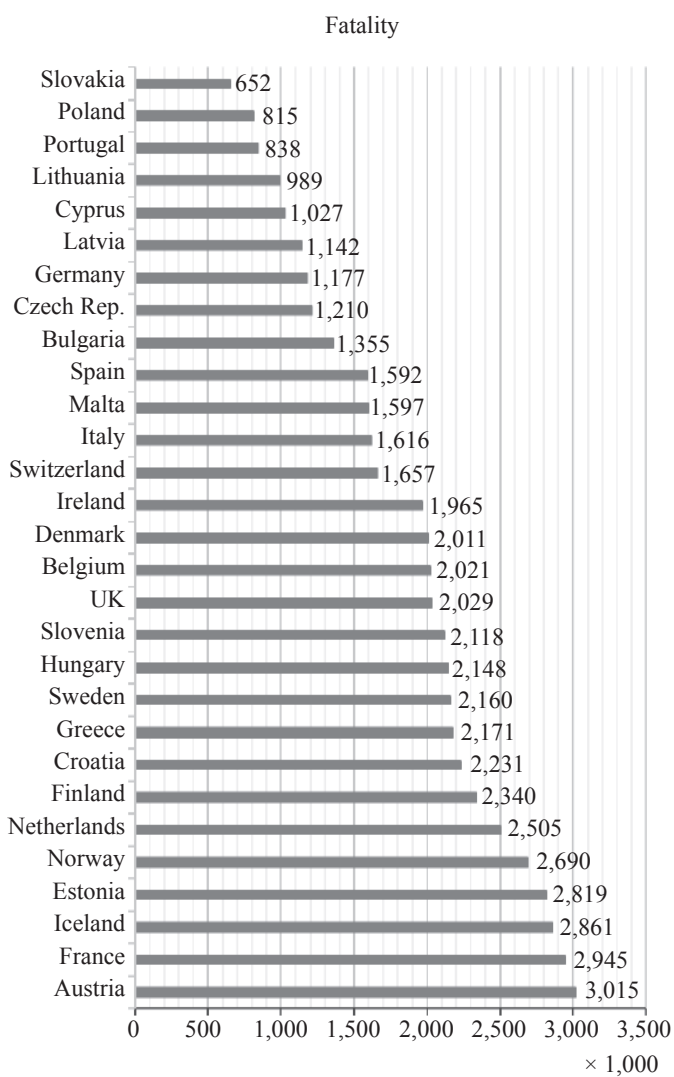

average, these values vary widely in Europe depending on the result of the accident (death or serious injury) and the country (Figure 2).

In some countries compensation has been legally standardised, so an important part of traffic accident costs can be determined objectively and equally for all the affected. This scale guarantees fair and equitable compensation for the entire population in equal circumstances. Undoubtedly, due to its size, one of the most relevant future costs is that which appears when an accident generates a situation of permanent disability or great disability in a victim.

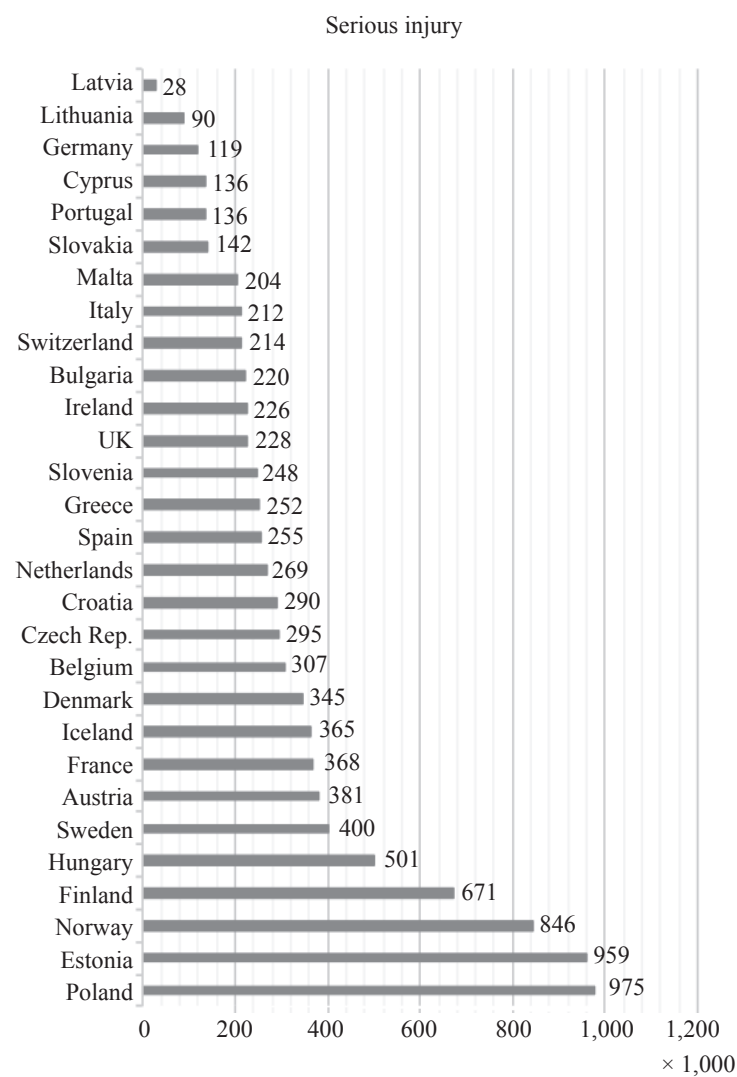

Figure 2 - Comparison of cost per accident (deceased or seriously injured) in Europe (2015), in thousands $€$ [8] 
For this reason, the aim of this paper is to establish the procedure for standardising the cost of lost production for victims who have been incapacitated by traffic accidents. This makes it possible to homogeneously determine the cost of production loss for all victims involved. The main conclusion is that a series of principles has been established for the standardisation of costs that covers the valuation of work loss for the majority of traffic accident victims. However, there are cases that are not the norm that should be taken into account and if the model is applied in Europe, the heterogeneity of the cost per disabling accident must be explained by different factors involved in the economic compensation: salary levels, mortality, and legal framework.

This paper is organised as follows: Section two reviews the classification of different components of road crashes costs as well as the methods used for valuation, looking at the methodology used to standardise the cost of lost production. The third Section applies this standardisation to Spain. The fourth Section discusses the main results finishing with relevant conclusions and recommendations derived from the work and ends with a bibliography and appendices with the relevant characteristics of public disability coverage in Spain.

\section{BASIC HYPOTHESIS}

\subsection{Valuation methods}

Since 1980s, the methods of evaluating different concepts arising from traffic accidents have been identified $[9,10]$. Furthermore, COST 313 Project [11], British Government [12, 13], the Asian Development Bank [14], and the World Bank [15] have also developed guidelines for assessing the costs of road accidents.

According to the international principles for the valuation of road accidents (COST 313 in [11]; SafetyCube in [7]), there are three main valuation methods (Figure 3).
Concretely,

- the restitution cost approach focuses on the valuation under the hypothesis of non-occurrence of an accident, such as direct medical and vehicle repair costs. It corresponds to the direct cost of an accident [16] and it is the appropriate method for assessing medical costs [17], property damage, and administrative costs.

- the Human Capital (HC) approach is applied mainly to value the loss of profit [7]. This approach depends on the current employment situation and the future earnings projection of the victim. Even if a person is unemployed, they contemplate the option of entering the labour market [18]. In fact, this loss of job opportunity can affect the economy in general by losing the consumption capacity [19]. It also includes a discount factor or money update that decreases the weight of payments by bringing forward the future costs [20].

- the Willingness-to-pay (WTP) approach is usually the model used to fix the moral damage produced by the road crash, although there are alternatives, such as the value resolved in the courts for the loss of life $[19,21]$ or the value of insurance premiums paid to cover the traffic accidents [18, 22-24]. This method is complementary to $\mathrm{HC}$ [25] and it is therefore, recommended to assess the loss of quality of life and the moral damage due to an accident [26].

Many of the concepts that make up the cost of accidents can be objectively valued using the restitution cost approach. However, others depend directly on people (human cost to be valued by WTP) or on people's own characteristics (production loss to be valued by $\mathrm{HC}$ ).

However, production loss can be valued [27] with the HC method. The HC method is used for the production loss while the WTP method is used for the quality of life [28]; they are therefore, complementary [25]. Thus, the HC method is chosen in

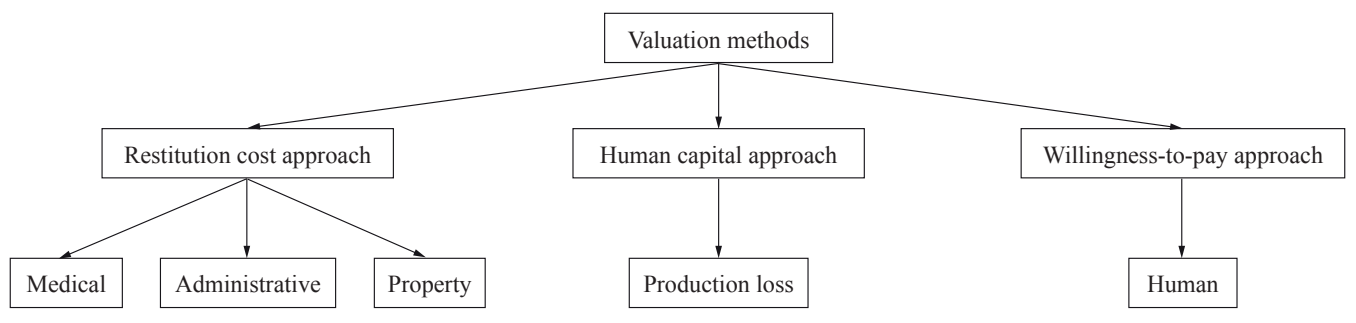

Figure 3 - Classification of methods for evaluating road accidents [11] 
countries, such as Belgium, the United Kingdom, Germany, Italy [29-31], to standardise the traffic accident compensation according to the outcome of an accident by reducing the number of legal disputes [32]. There are multiple factors that make it particular, although perhaps the severity of injury has the greatest impact on the economic damage suffered by a victim. This damage is defined by the loss of profit derived from their work activity since they cannot work temporarily (minor damage) or permanently (death, serious damage, or disability).

The main part of the cost would be made up of:

- loss of working capacity due to death, disability or damage;

- loss of non-working capacity, for accident victims who carry out housework, childcare, voluntary work;

- loss of job projection due to training for job promotion, finding a job or training.

The initial parameters necessary to determine the production loss are salary or the equivalent, depending on the activity undertaken at the time of the accident [18], and the age of the victim. Both parameters are known. From the road accident onwards, the wage flows are conditioned by the injured person's existence, so a series of assumptions must be established in order to carry out a personalised actuarial valuation for any accident where there is a victim (deceased or disabled). Part of the hypothesis is derived from the victim's age, the applicable mortality table and whether the victim is disabled. Other hypotheses limit the future evolution of significant economic magnitudes: salaries, pensions, and the interest rate. This valuation is framed within an institutional framework that limits the working period of a worker (retirement age) as well as the calculation of the public pensions originated by the accident.

In order to facilitate this assessment, for example, the United Kingdom uses periodically updated actuarial tables [33]. Their application of future income is foregone and according to the age of the victim gives rise to compensation. This procedure is called compound vector or multiplier-multiplicand method. Compensation is the result of applying the product of the multiplier (usually an economic loss) by the multiplicand (the value of the current value over several years in which the economic loss would be paid). The Government Actuary's Department prepares the tables after consulting actuaries, accountants and lawyers [34] and new revisions are published every two years.

In Spain, Law 35/2015, of 22 September (Scale [35]) establishes a procedure similar to that of the multiplier-multiplicand, although based on two known data (age and salary) it obtains the compensation. This is due to its design, which has included direct correspondence between the income foregone by a victim and the income they will receive after a claim.

\subsection{Actuarial valuation of production loss}

The valuation must consider the future economic flows to be received by a victim, prior to and in the situation of disability. Periodic financial compensation is affected by a random event such as death. Therefore, let $X$ be the random variable "age of death of a new-born" and let $x$ be any age of the person. The death distribution function is represented by $F$ :

$$
F(x)=P(X \leq x)
$$

where $x \geq 0$ and $F(0)=0$

On the contrary, the survival function gives the probability that a new-born will reach age $x$ alive. This is,

$s(x)=P(X>x)=1-F(x) \quad \forall x \geq 0$

The derivative function $f(x)$ from the death function $F(x)$ results in

$$
f(x)=\frac{d F(x)}{d x}=-\frac{d s(x)}{d(x)}=-s^{\prime}(x)
$$

being the instant mortality rate $\left(\mu_{x}\right)$,

$$
\begin{aligned}
& \mu_{x}=\frac{f(x)}{1-F(x)} \\
& \text { As } \mu_{x} \geq 0 \text { and } f(x)=-s^{\prime}(x) \text { then, } \\
& \mu_{x}=-\frac{s^{\prime}(x)}{s(x)}=-\frac{d \ln (s(x))}{d x}
\end{aligned}
$$

Therefore, the probability that a person of age $x$ will reach age $x+t\left({ }_{t} p_{x}\right)$ can be defined as

${ }_{t} p_{x}=e^{-\int_{x}^{x+t} \mu_{x} d z}$

Likewise, $v_{T}$ is the corresponding financial factor from the $t$-th instant to the origin or initial moment, being the financial present value function defined by the instantaneous interest rate $(\delta(t))$,

$v_{T}=e_{0}^{-\int_{0}^{T} \delta(t) d t}$ 
The present compensation value of the compensation corresponding to the $t$-th moment will be:

$Z_{T}=b_{T} \cdot v_{T}$

which will also be a random variable since both values $b_{T}$ and $v_{T}$ depend on the random variable of lifetime to death.

If the payment function $\left(b_{T}\right)$, the survivorship function $(s(x))$ and the financial function $\left(v_{T}\right)$ are known, it is possible to calculate the expected value of the payments (assuming the duration until retirement age $r$ ) or the actuarial value at age $x\left(L_{x}\right)$ as,

$$
L_{x}=E\left(Z_{T}\right)=E\left(b_{T} \cdot v_{T}\right)=\int_{x}^{r} b_{t} \cdot e^{-\int_{x}^{r} \mu_{x} d t} \cdot e^{-\int_{x}^{r} \delta(t) d t} \cdot d t
$$

As the economic compensation for Production Loss (PL) is defined by the loss of earning capacity for working and due to the net decrease in income from work and up to the age of entering the retirement $(r)$,

$P L=V A A_{I N C_{x}}-V A A_{P S S}$

where,

$x \quad-$ age of the injured at the time of valuation;

$V A A_{I N C_{x}}$-present actuarial value of the income that the injured party would be entitled to receive at the time of valuation;

$V A A_{P S S_{x}}$-present actuarial value of the amount to be received as consequence of the social security Disability Pension at the time of valuation.

Specifically, it will be:

$$
\begin{aligned}
P L= & \int_{0}^{r} I N C_{t} \cdot e^{-\int_{x}^{r} \mu_{x} d t} \cdot e^{-\int_{x}^{r} \delta(t) d t} \cdot d t- \\
& -\int_{0}^{r} P S S_{t} \cdot e^{-\int_{x}^{r} \mu_{x} d t} \cdot e^{-\int_{x}^{r} \delta(t) d t} \cdot d t
\end{aligned}
$$

where,

$I N C_{t} \quad-$ victim's income that they would have received at time $t$, if the accident had not occurred;

$\mathrm{PSS}_{t} \quad$-social security disability pension the victim receives at time $t$, due to the accident;

$e_{x}^{-\int_{x}^{r} \delta(t) d t}-$ financial update factor from the $t$-th instant to the origin or initial moment; $e^{-\int_{x}^{r} \mu_{x} d t}-$ probability that a person of age $x$ will reach age $x+t$ taking into account the mortality table according to the situation of the injured person before the accident; $e^{-\int_{x}^{r} \dot{\mu}_{x} d t}$-probability that a person of age $x$ will reach age $x+t$ taking into account the mortality table according to the situation of the injured person after the accident.

In view of the above expression, three factors can be found that affect this lost profit:

Biometric factor. In order to calculate the present actuarial values, a number of assumptions are needed regarding the evolution of people's lives. These are the mortality tables, both for the disabled and non-disabled situations. They depend on the year of birth and gender.

Economic factor. These are the values that refer to the victim's income.

a) Periodic income. This is income received during the year prior to the accident or the average of the income obtained in the three years prior to the accident, if this is higher.

$$
I N C_{x}=\max \left(I N C_{x-1} ; \frac{I N C_{x-1}+I N C_{x-2}+I N C_{x-3}}{3}\right)
$$

b) In the event that the injured party is waiting to enter the labour market, the period of economic loss shall begin at the earliest at 30 years of age and end at retirement age. In this case, $150 \%$ of the minimum salary (MS) in the case of absolute incapacity for work or $55 \%$ if it is a total permanent incapacity computed as income foregone. However, if you have a higher level of education these amounts are increased by $20 \%$.

c) Injured with dedication to unpaid household chores. Valued at the equivalent of an annual MS. In addition, it is increased by $10 \%$ for each minor, disabled person, or person over sixty-seven years of age who lives in the family unit, with the maximum being $150 \%$ of the MS (absolute incapacity for work) or 55\% (total permanent incapacity).

Institutional factor. Corresponds to those parameters set by the administration, such as retirement age, percentage of coverage and public social security pension. 


\section{RESEARCH RESULTS}

This section applies the standardisation of loss of earnings due to disability resulting from a traffic accident in Spain. For this purpose Law 35/2015, of 22 September, regarding the reform of the system for the valuation of damages caused to persons in traffic accidents, is taken into account, as are the actuarial technical bases of the system for the valuation of damages caused to persons in traffic accidents.

\subsection{Technical base}

The specific values of different factors are as follows:

Biometric factor. The unisex mortality tables PEIB2014 created in Spain for different types of permanent disability are applied. These tables take into account the insurance sector's mortality experience. In this way, life expectancy as applied to the Partial and Total degrees (Levels 1 and 2) is greater than in the Absolute and Great Disability degrees (Levels 3 and 4) (Table 1)

Table 1 - Life expectancy by levels from table PEIB 2014 [36]

\begin{tabular}{||c|c|c||}
\hline Age & Levels I \& II & Levels III \& IV \\
\hline \hline 0 & 67.49 & 56.41 \\
\hline 10 & 62.37 & 51.82 \\
\hline 20 & 52.67 & 42.75 \\
\hline 30 & 43.59 & 36.07 \\
\hline 40 & 34.86 & 30.54 \\
\hline 50 & 27.30 & 25.40 \\
\hline 60 & 20.84 & 19.90 \\
\hline 70 & 14.41 & 13.66 \\
\hline 80 & 8.24 & 8.08 \\
\hline 90 & 4.03 & 3.79 \\
\hline 100 & 0.50 & 0.50 \\
\hline
\end{tabular}

Economic factor. These are the victim's incomes.

a) Income revaluation. According to the actuarial technical bases, it takes a value, $u=1.5 \%$. b) Revenues prior to the causative event are deflated to the consumer price index (CPI) to determine the quotation basis, estimated at $p c i=2 \%$.

c) Interest rate of the update. The actuarial technical bases set it at $i=3.5 \%$.

Institutional factor. Corresponds to those parameters set by the administration, such as retirement age, percentage of coverage, and public social security pension.

a) Retirement age: 67;

b) Degree of permanent disability. Coverage follows the same definition, monthly payments and percentages as those corresponding to the public social security system (Table 2).

c) Resulting public pension. Due to the degree of disability, the injured party receives a public pension estimated as the quotient that results from dividing the sum of the contribution base of the injured party during an uninterrupted period of 24 months by 28, prior to the causative event.

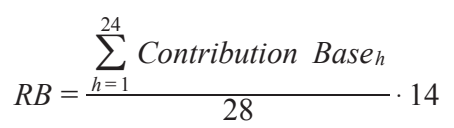

The contribution base corresponds to the victim's income during those two years; the amount is equivalent to the annual amount.

\subsection{Results}

With these values, the loss of working has been calculated in a double entry table based on the age of the injured person and salary income. This paper uses fictitious data, which does not represent a specific individual, nor does it include any personal data. Therefore, this study does not require any ethical permit.

The starting point is the set of ages where the injured person may have the capacity to work and, therefore, the accident produces a reduction in this capacity, $\forall x \in[16 ; 67]$.

Table 2 - Summary of coverage for permanent disability (PD)

\begin{tabular}{||c|c|c||}
\hline Situation & Loss & Pension \\
\hline \hline Partial PD & 2 annuities & $P_{I P P}=24 \cdot R B$ \\
\hline Total PD & $\begin{array}{c}55 \% \text { up to } 55 \text { years old } \\
75 \% \text { from } 55 \text { years old }\end{array}$ & $\begin{array}{c}P_{T P D}=55 \% \cdot R B \text { if } x \leq 55 \text { years old } \\
P_{T P D}=75 \% \cdot R B \text { if } x \leq 55 \text { years old }\end{array}$ \\
\hline Absolute PD & $100 \%$ & $P_{A P D}=100 \% \cdot R B$ \\
\hline Severe disability & & \\
\hline
\end{tabular}




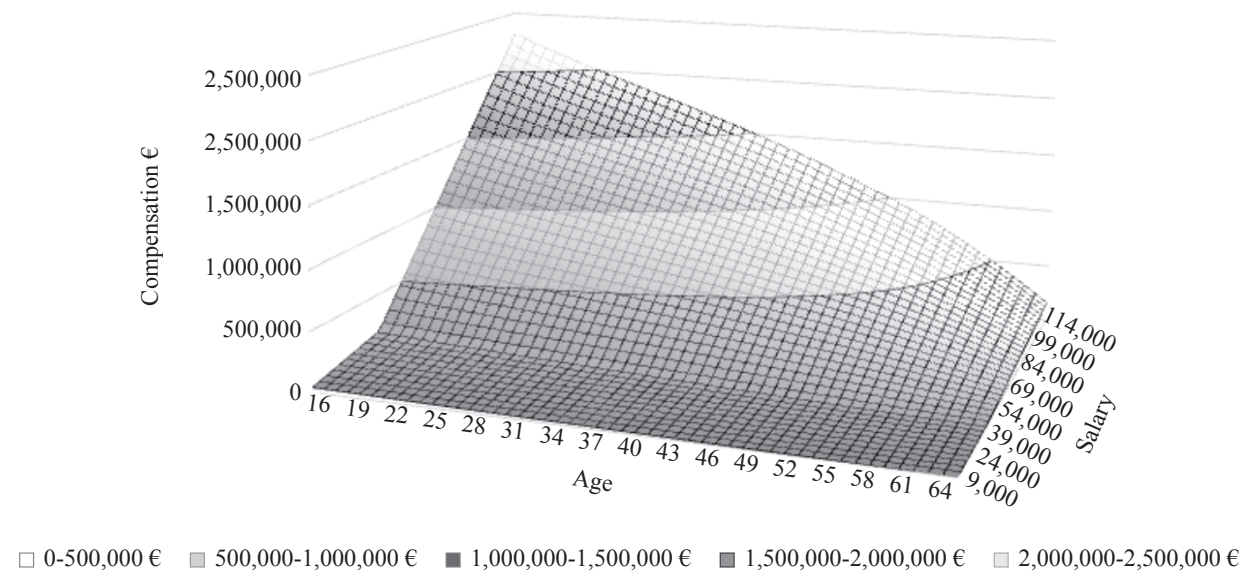

Figure 4 - Compensation for absolute permanent disability according to age and annual income

As far as the salary is concerned, we have considered salary brackets from $€ 9,000$ per year to $€ 120,000$ per year, in brackets of $€ 3,000$ per year, $\forall s_{x} \in[9,000 ; 120,000]$.

The above criteria result in a set of values ordered by age and income, where the compensation amount for a road accident is at the corresponding intersection (Figure 4).

Thus, a 38-year-old accident victim with an annual income of $€ 51,000$ would achieve a productivity loss of $€ 285,974$. However, if there were no direct relationships between the salary and the pension it can generate, as in the case of a worker receiving a minimum pension, then the compensation would be: $P L=764,487.72$.

It is clear that, if there is no compliance between the salary and the pension generated, the standardisation procedure does not include the real production loss. The same occurs with other factors such as retirement age or even the use of mortality tables that are appropriate to the victim's gender.

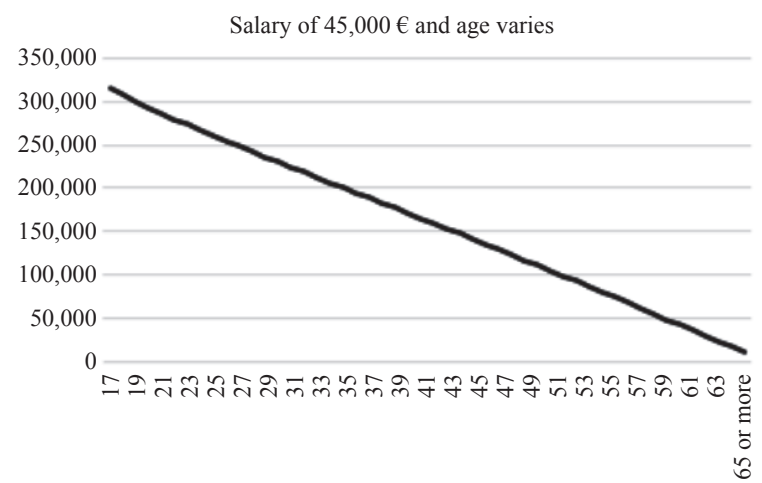

If an analysis is made of how compensation for the same salary varies, depending on the age of the victim, or an analysis is conducted for the same age, depending on the victim's salary, we have the following (Figure 5):

- The older you are, the minor economic compensation there is because there is less time to lose production. As valuation is considered up to the retirement age, no account is taken of the job loss of victims over that age.

- The higher the salary, the greater the economic compensation because of the differential in labour productivity over the revaluation of pensions.

- It should be noted that there is a point at which economic compensation increases sharply. This is due to the institutional factor of Social Security. The existence of a maximum public pension is common; therefore, accident victims with annual salaries that are higher than the maximum pension will suffer a greater loss of work, and the compensation for the accident will also be greater.

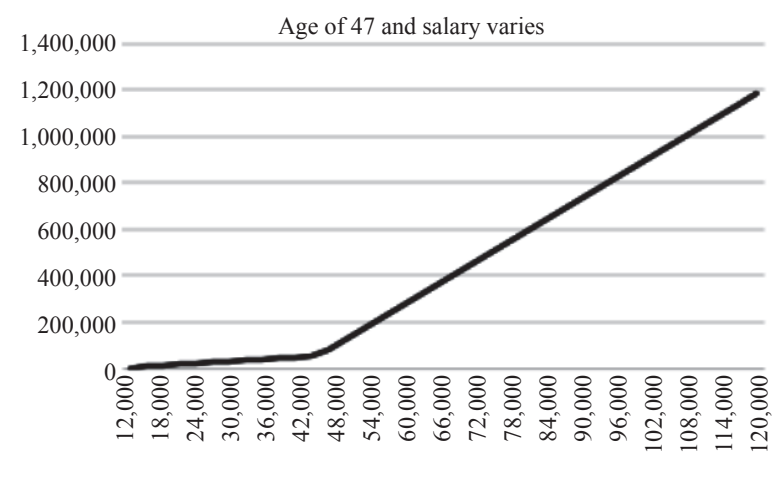

Figure 5 - Compensation for variations in age or salary 


\section{DISCUSSION}

There is extensive evidence on the socio-economic effect of traffic accidents. Although their cost is globally estimated, without taking into account the specific group they affect (individuals, insurers, government, etc.), the particularised information may be relevant for each of them.

Its direct effect on an injured individual and on society is undeniable. In an analysis of accidents effect on an individual, the valuation of the accident contemplates the damage produced directly to individuals and to their property. However, in a socio-economic valuation, in addition to the above, the economic expenses and alterations produced by an accident are taken into account not only in the individual, but also in the society and economy of the country. The standardisation of cost leads to reduced expenses of justice, which consequently lead to cheap and fast administrative resolutions.

Although the guidelines for standardisation may be rigid, their aim is to resolve most cases without going to courts. Therefore, only the cases that do not fall within the above assessment and hypotheses should be assessed individually. These would be:

\section{Institutional factor}

- Resulting public pension is different from the one foreseen (occupational accident, application of concurrent pension, inverse working life, etc.).

- Different retirement age (the scale contemplates only a single age at 67 ).

- Contribution base is different from that which corresponds to the injured party's income (if there is freedom of choice of contribution, minimum and maximum ceilings).

\section{Economic factor}

- Periodic income is different from the stipulated average of the last three years prior to the accident.
- Different revaluation of income (public sector, technology, remuneration by objectives, in kind, etc.).

\section{Biometric factor}

- The mortality tables must be specific to each accident victim's situation and be based on both the general population mortality rates before an accident and the disabled mortality rates if a victim is disabled. It is acceptable to apply a differentiated mortality to an injured person for all the income they would have received if the accident had not occurred, by means of, for example, the same mortality tables indicated for the general population in the case of loss of earnings from death.

- This would correspond to actuarial justice according to an individual's life expectancy and physical condition, determining the estimated real loss.

- If, at the time of the accident, the injured person was already incapacitated, it would be acceptable to use the same tables (unless there is a different degree of incapacity).

The compensation calculated via scale procedure must be completed with the compensation for loss of welfare that is usually obtained by the willingness-to-pay approach.

With the methodology exposed and for the rest of the cases it is possible to know the economic compensation by a table based on only two known values (Figure 6):

- Salary, which reflects the victim's initial annual net income amount that indirectly determines the public permanent disability pension to which the injured party is entitled;

- Age, which includes the risk of the injured party's death in each period considered, as well as the money update based on the fixed interest rate.

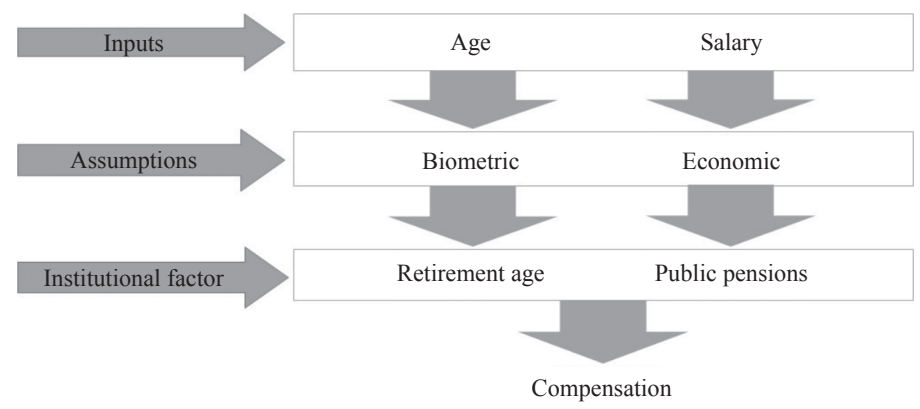

Figure 6-Standardisation procedure 
Based on the principles included in the biometric, economic and institutional factors, it follows that

$$
P L=f(x ; P I N G ; A S S ; I F)
$$

Thus, compensation is a function of age, income, assumptions made and the corresponding institutional factor (legal framework).

In fact, vehicle insurers must adjust to the new order of compensation. It is of great relevance not only to personal and vehicle data, but also to other user data such as salary and social data which, although maybe the key in a business model, are vital to determine the claim intensity in an insurance company.

\section{CONCLUSION}

This paper sets out a procedure for calculating the production loss costs of road accident victims who become disabled. This procedure is standard and establishes the principles and hypotheses. However, there are several cases outside the norm due to their peculiarity. The standardisation of the value represented by a victim's production loss provides a homogeneous quantitative assessment by unifying criteria, ensuring scientific support and reducing the amount of litigation in the administrative and judicial processes of the traffic accidents in which they were injured.

The procedure itself is a contribution to simplifying the determination of remuneration in such cases, which would ultimately be able to reduce, to a certain extent, the workload of the courts. However, due to the small number of variables, it may be more reasonable to expect that the proposed procedure has more of an advisory than a binding role in determining the amount of compensation for the injured parties. It is therefore, a solid basis for further research in this direction and it needs a quality upgrade to fulfil the desired mission.

The standardization of the procedure clashes with the different realities of each country. Although the procedure is standard, it would obtain different values in each country. The heterogeneity of the cost per disabling accident in Europe must be explained by the different factors that influence the economic compensation. In a framework that tends towards harmonisation in all countries, harmonisation must also be carried out in the calculation of lost production costs. If a standard procedure were used in all countries, the cost divergence would be given:

- in relation to inputs, by the different salary levels existing in each country;

- with regard to assumptions, the different mortality table and the country-specific economic assumptions;

- in terms of the institutional factor, it would depend on the legal framework of the social security system setting the retirement age and the permanent disability pension.

This is an area still to be researched.

\section{ACKNOWLEDGEMENTS}

This paper was supported by the Consolidated Research Group Eusko Jaurlaritza/Gobierno Vasco EJ/GV: IT 897-16 and by the University-Society Research Project UPV/EHU US 17/20. The authors acknowledge the linguistic help from Julie Walker.

\author{
J. IÑAKI DE LA PEÑA, Ph.D. ${ }^{1}$ \\ (Corresponding Author) \\ E-mail: jinaki.delapena@ehu.es \\ MIGUEL A. PENA-CEREZO, Ph.D. ${ }^{2}$ \\ E-mail: miguelangel.pena@ehu.es \\ OLGA FOTINOPOULOU, Ph.D. ${ }^{2}$ \\ E-mail: olga.fotinopulos@ehu.es \\ ${ }^{1}$ Facultad de Economía y Empresa, \\ Universidad del País Vasco (UPV/EHU) \\ Departamento de Economía I \\ Avda. Lehendakari Agirre, 83, 48015 Bilbao, España \\ ${ }^{2}$ Facultad de Economía y Empresa, \\ Universidad del País Vasco (UPV/EHU) \\ Departamento de Economía II \\ C/ Comandante Izarduy, 23, 01006 Vitoria-Gasteiz, España
}

\section{COSTE DE LA PÉRDIDA LABORAL POR INCAPACIDAD PERMANENTE CAUSADA POR ACCIDENTE DE CIRCULACIÓN}

\section{RESUMEN}

Los accidentes de tráfico dejan secuelas de por vida y si la víctima es inválida, producen una pérdida económica debido su diferencial de ingresos. Este valor es muy divergente en Europa, aunque si existe un consenso sobre qué componentes de coste y métodos de valoración. Sin embargo, algunos países han legalizado la compensación financiera para que se calcule de forma objetiva y equitativa para todos los afectados. Este trabajo establece el procedimiento de normalización para calcular la pérdida de las víctimas de accidentes de tráfico incapacitadas. Se emplea una metodología actuarial que relaciona los insumos conocidos (edad y salario). Este procedimiento proporciona principios e hipótesis generales y también 
localiza los casos que requieren una valoración particular. El coste estándar así calculado permite una compensación homogénea, justa y equitativa para todos los implicados en circunstancias similares.

\section{PALABRAS CLAVE}

accidente de tráfico; lesión; discapacidad; valor de la vida; valoración actuarial;

\section{REFERENCES}

[1] Herbst AJ. The cost of medical and rehabilitation care for road accident victims at public hospitals. In: Report of the road accident fund commission. 2002. Pretoria: Ministry of Transport. Available from: http://docplayer. net/927556-Annexure-j-the-cost-of-medical-and-rehabilitation-care-for-road-accident-victims-at-public-hospitals.html [Accessed 18 ${ }^{\text {th }}$ January 2019].

[2] Dalal K, Svanström L. Economic burden of disability adjusted life years (DALYs) of injuries. Health. 2015;7(4): 487-494. Available from: doi:10.4236/health.2015.74058 [Accessed $18^{\text {th }}$ January 2019].

[3] Dalal K, Janson B. Cost calculation and economic analysis of violence in low-income country: A model for India. African Safety Promotion: A Journal of Injury and Violence Prevention (ASP). 2007;5(1): 45-56.

[4] EC-European Commission. Towards a European Road SafetyArea:PolicyOrientationsonRoadSafety2011-2020. Brussels: European Commission; 2010. Available from: https://ec.europa.eu/transport/road_safety/sites/roadsafety/files/pdf/com_20072010_en.pdf $\left[\right.$ Accessed $18^{\text {th }}$ January 2019].

[5] World Bank. Global road safety facility strategic plan 2013-2020. Washington: World Bank/Global Road Safety Facility; 2013. Available from: http://siteresources.worldbank.org/INTTOPGLOROASAF/Resources/ GRSF-strategic-plan-2013-2020.pdf [Accessed 18 ${ }^{\text {th }}$ January 2019].

[6] WHO - World Health Organization. Global Status Report on Road Safety 2018. Geneva: World Health Organization; 2018. Available from: https://www.who.int/violence_injury_prevention/road_safety_status/2018/English-Summary-GSRRS2018.pdf [Accessed $18^{\text {th }}$ September 2019].

[7] Wijnen W, Weijermars W, Vanden Berghe W, Schoeters A, Bauer R, Carnis L, Elvik R, Theofilatos A, Filtness A, Reed S, Perez C, Martensen H. Crash cost estimates for European countries, Deliverable 3.2 of the H2020 project SafetyCube, 2017. Available from: https://dspace.lboro. ac.uk/dspace-jspui/bitstream/2134/24949/1/D32-CrashCostEstimates_Final.pdf [Accessed $18^{\text {th }}$ January 2019].

[8] Wijnen W, Weijermars W, Schoeters A, Van den Berghe W, Bauer R, Carnis L, Elvik R, Martensen H. An analysis of official road crash cost estimates in European countries. Safety science. 2019;113: 318-327. Available from: doi:10.1016/j.ssci.2018.12.004 [Accessed 30 ${ }^{\text {th }}$ September 2019].

[9] Hills PJ, Jones-Lee MW. The costs of traffic accidents and evaluation of accident prevention in developing countries. In: PTRC Summer Annual Meeting, 13-16 July 1981, University of Warwick. London: PTRC Education and Research Services; 1981.
[10] Hills PJ, Jones-Lee MW. The Role of Safety in Highway Investment Appraisal for Developing Countries. Accid Anal Prev. 1983;15: 355-369. Available from: https://www.sciencedirect.com/science/article/abs/ pii/0001457583900143 [Accessed 18 ${ }^{\text {th }}$ January 2019].

[11] Alfaro JL, Chapuis M, Fabre F. (Eds.) Socio-economic cost of road accidents: final report of action COST 313. Brussels: Commission of the European Community; 1994.

[12] TRL - Transport Research Laboratory. Costing Road Accidents in Developing Countries. Overseas Road Note 10. Crowthorne: Transport Research Laboratory; 1995. Available from: https://trl.co.uk/reports/ORN10 [Accessed $18^{\text {th }}$ January 2019].

[13] BRS - Babtie Ross Silcock, TRL - Transport Research Laboratory. Guidelines for estimating the costs of road crashes in developing countries; 2003. Available from: https://www.gov.uk/dfid-research-outputs/guidelinesfor-estimating-the-cost-of-road-crashes-in-developingcountries [Accessed $18^{\text {th }}$ January 2019].

[14] ADB - Asian Development Bank. Road Safety Audit for Road Projects: An Operational Tool Kit. Manila; 2003. Available from: https://www.irfnet.ch/files-upload/member_area-pdf-files/RS_WG/Annex/Road-Safety-Auditfor-Road-Projects.pdf [Accessed $18^{\text {th }}$ January 2019].

[15] World Bank. Valuation of accident reduction. Transport Note No. TRN-16. Washington: World Bank; 2005. Available from: https://openknowledge.worldbank.org/ handle/10986/11799

[16] ERSO. Cost-benefit analysis. European Road Safety Observatory; 2006 November 18. Available from: http:// erso.swov.nl/knowledge/content/08_measures/cost_benefit_analysis.htm [Accessed $18^{\text {th }}$ January 2019].

[17] Bambach MR, Mitchell RJ. Estimating the human recovery cost of seriously injured road crash casualties. Accident Analysis and Prevention. 2015;85: 177-185. Available from: https://www.sciencedirect.com/science/ article/pii/S0001457515300701 [Accessed 30 th September 2019].

[18] Wijnen W, Stipdonk H. Social costs of road crashes: an international analysis. Accid Anal Prev. 2016;94: 97-106. Available from: https:/www.sciencedirect.com/science/ article/pii/S0001457516301592

[19] Baum H, Kranz T, Westerkamp U. Volkswirtschaftliche Kosten durch Straßenverkehrsunfälle in Deutschland. Heft M208. Bergisch Gladbach: Bundesanstalt für Straßenwesen; 2007.

[20] Boardman AE, Greenberg DH, Vining AR, Weimer DL. Cost-benefit. Analysis. Concepts and Practice. Fourth edition. New Jersey: Pearson Prentice Hall; 2011.

[21] BITRE. Costs of road crashes in Australia 2006. Canberra: Bureau of Infrastructure, Transport and Regional Economics, Research report 118, 2009. Available from: https://bitre.gov.au/publications/2010/files/report_118. pdf [Accessed $18^{\text {th }}$ January 2019].

[22] De Blaeij A, Florax RJGM, Rietveld P, Verhoef E. The value of statistical life in road safety: A meta-analysis. Accid Anal Prev. 2003;35(6): 973-986. Available from: https://www.sciencedirect.com/science/article/pii/ S0001457502001057 [Accessed $18^{\text {th }}$ January 2019].

[23] Elvik R. An analysis of official economic valuations of traffic accident fatalities in 20 motorized countries. Accid Anal 
Prev. 1995;27(2): 237-347. Available from: https:/www. sciencedirect.com/science/article/pii/000145759400060Y [Accessed $18^{\text {th }}$ January 2019].

[24] Trawén A, Maraste P, Persson U. International comparison of costs of a fatal casualty of road accidents in 1990 and 1999. Accid Anal Prev. 2002;34(3): 323-332. Available from: https://www.ncbi.nlm.nih.gov/pubmed/ 11939361 [Accessed $18^{\text {th }}$ January 2019].

[25] Wijnen W, Wesemann P, de Blaeij A. Valuation of road safety effects in cost-benefit analysis. Eval Program Plann. 2009;32: 326-331. Available from: https://www.sciencedirect.com/science/article/pii/ S0149718909000597 [Accessed $18^{\text {th }}$ January 2019].

[26] Schoeters A, Wijnen W, Carnis L, Weijermars W, Elvik $\mathrm{R}$, Johanssen $\mathrm{H}$, Vanden Berghe W, Filtness A, Daniels S. Costs related to serious injuries. Deliverable 7.3 of the H2020 project SafetyCube; 2017. Available from: https://dspace.lboro.ac.uk/dspace-jspui/bitstream $/ 2134 / 25111 / 1 /$ SafetyCube $\% 20$ Deliverable $\% 20$ $7.3 \% 20-\% 20$ Costs $\% 20$ related $\% 20$ to $\% 20$ serious $\% 20$ road\%20injuries.pdf [Accessed $18^{\text {th }}$ January 2019].

[27] Freeman AM. The Measurement of Environment and Resource Values: Theory and Methods. Second edition. Washington: Resources for the future; 2003.

[28] Ainy E, Soori H, Ganjali M, Le H, Baghfalaki T. Estimating Cost of Road Traffic Injuries in Iran Using Willingness to Pay (WTP) Method. PLoS ONE. 2014;9(12): e112721. Available from: doi:10.1371/journal.pone.0112721 [Accessed $18^{\text {th }}$ January 2019].

[29] EU - Eropean Union. Compensation of victims of cross-border road traffic accidents in the EU. Comparison of national practices, analysis of problems and evaluation of options for improving the position of cross-border victims; 2009. Available from: http://ec.europa.eu/ civiljustice/news/docs/study_compensation_road_victims_en.pdf [Accessed 18 $8^{\text {th }}$ January 2019].
[30] Lucas P. Valoración y reparación del daño corporal en Bélgica [Assessment and reparation of bodily harm in Belgium]. In: Borobia Fernandez C. (ed.) Valoración del daño corporal. Legislación, metodología y prueba pericial médica. Barcelona: Ed. Masson; 2006. p. 471-479.

[31] Markesinis B, Coester M, Alpa G, Ullstein A. Compensation for personal injury in English, German and Italian Law. Cambridge: Cambridge University Press; 2005.

[32] Rogers WVH. Damages for non-pecuniary loss in a comparative perspective. New York: Springer; 2001.

[33] Lewis R, Mcnabb R, Robinson H, Wass V. Loss of earnings following personal injury. Do the Courts adequately compensate injured parties? Econ J. 2003;113: 568-584. Available from: https://www.jstor.org/stable/3590254?seq=1\#page_scan_tab_contents [Accessed $18^{\text {th }}$ January 2019].

[34] Butt Z, Haberman S, Verrall R, Wass V. Calculating compensation for loss of future earnings: Estimating and using work life expectancy. J R Stat Soc Ser A Stat Soc. 2008;171(4): 763-805. Available from: http://openaccess.city.ac.uk/4041/ [Accessed $18^{\text {th }}$ January 2019].

[35] Law 35/2015, de 22 de septiembre, de reforma del sistema para la valoración de los daños y perjuicios causados a las personas en accidentes de circulación [Reform of the system for the valuation of damages caused to persons in traffic accidents]. BOE 228, de 23 de septiembre, 84473-84979. Available from: https://www.boe.es/diario_boe/txt.php?id=BOE-A-2015-10197 [Accessed $18^{\text {th }}$ January 2019].

[36] Sáez De Jáuregui L. Baremo de autos. Bases técnicas actuariales en el nuevo sistema. Hipótesis económico-financieras y biométricas del sistema de valoración [Cars' Scale. Actuarial technical bases in the new system. Economic-financial and biometric hypotheses of the valuation system]. Jornada de UNESPA sobre el Baremo de Autos. 29 de octubre. Madrid, 2014. 